\title{
The Phenomenon Flypaper Effect in Balanced Funds, Regional Revenue and Surplus Budget Funding of Economic Growth and Regional Expenditure in Districts/City East Java Province
}

\author{
Dr. Hadi Sumarsono ${ }^{1}$, Dr. Farida Rahmawati ${ }^{2}$

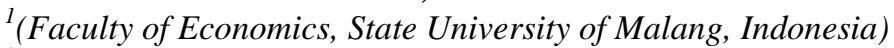 \\ ${ }^{2}$ (Faculty of Economics, State University of Malang, Indonesia)
}

\begin{abstract}
Implementation of regional autonomy as the government's efforts for the welfare society in accordance with the characteristic of each region. Implementation of the fiscal decentralization recurring phenomenon is the phenomenon of flypaper effect. Flypaper effect occurs when the local government responded to the regional expenditure larger than the central government transfer revenue. The purpose of research is to prove the phenomenon of flypaper in East Java Province period 2011-2015. This research uses quantitative analysis with a population of 29 districts and 9 cities in East Java province. Data were analyzed using panel data regression analysis with Eviews statistical test equipment. The result showed that regional revenue positively affects regional expenditure, general allocation fund positively affects regional expenditure, financing budget surplus positively affects regional expenditure, regional revenue positively effect on growth, positive effect on the regional expenditure growth at district/city in East Java Province. The result of the comparison coefficient general allocation of funds and region revenue indicate there has been a flypaper effect on region expenditure districts/cities in East Java Province period 2011-2015
\end{abstract}

Keywords: Flypaper Effect, Regional Expenditure, Economic Growth

\section{Introduction}

Implementation of regional autonomy is the focal point of government efforts for the welfare of the community in accordance with the characteristic of each region. Implementation of enhanced local autonomy with fiscal decentralization officially began on January 1, 2001. When the response to the major region expenditure more than the transfer of income, it can be said there is the phenomenon of flypaper effect. According to Law No. 32 of 2004 on local governments is the right authority and obligations of autonomous regions to organize and regulate their own affairs and interests of local communities in accordance with the legislation. Broadly speaking there are 7 that needs the attention of regional autonomy it self-becomes main goal (Top Destinations) namely: Public Services, Community Development, Community Participation, Competitiveness area, Public Welfare, Democracy and Equity and justice.

Implementation of enhanced local autonomy with fiscal decentralization officially began on January 1 , 2001. Sources reception area in the context of regional autonomy and fiscal decentralization is still dominated by the aid and assistance of the central government in the form of General Allocation Fund, Special Allocation Fund, and Revenue Sharing results. While the proportion of Special Allocation Fund is still relatively small. On the average national, regional revenue contributes only $12-15 \%$ of total local revenues, while approximately $70 \%$ still depend on contribution from central government assistance. Oates (1999) states that when the response is greater regional spending on transfers than his own income, then it is called flypaper effect (Halim, 2002). Flypaper effect is a phenomenon to a condition when the local government to respond to regional spending more than the transfer comes from region revenue.

Related to this, a lot of research has been discussed the flypaper effect. Other studies related to flypaper effect in East Java indicate occurred flypaper effect in East Java evidenced by the influence of general allocation fund to region expenditure more strongly than revenue (Ariwijaya, 2013). Meanwhile, other studies related to flypaper effect showed that the occurrence of flypaper effect in East Java mean that most of the district/city in East Java Province is more dependent on local revenue itself rather than the general allocation fund of the government (Arofi, 2015). This is also supported by research that suggests that Financing Budget Surplus take to effect positive against opportunistic behavior-budgeting, in which this research shows that Financing Budget Surplus large are closely related as a result of the rate of absorption is very small as a result of an error in the pattern of planning, both in terms of policy and technical (Megasari, 2015). Based on the above explanation it is necessary to do research on "The Phenomenon Flypaper Effect In Balanced Funds, Regional Revenue and Surplus Budget Funding of Economic Growth and Regional Expenditure In Districts/City Province East Java". 


\subsection{Regional Autonomy}

\section{II. theoretical framework}

Autonomy is derived from the Greek outo and nomous, auto which means "alone" while nomous means "law" or "regulation" (Simanjuntak, 2013). Regional autonomy means is granting the rights, powers or duties of a region to organize and manage their own household in accordance with the prescribed rules. Regulation of regional autonomy in Indonesia has been established in the legislation.Legislation regional autonomy in Indonesia several times through the renewal/amendment.

Table 1.1 Regional Autonomy Law in Indonesia

\begin{tabular}{|l|l|l|l|}
\hline No. & Period / Era Government & Constitution & About \\
\hline 1 & Dutch colonial & Regulation 1903 & Decentralisatie wet \\
\hline 2 & Dutch colonial & Bestuurshervormings wet 1922 & Basic Regulation Public Institution Indies \\
\hline 3 & Physical revolution & Law No. 1/1945 & Position Local National Committee \\
\hline 4 & Physical revolution & Law No. 22/1948 & $\begin{array}{l}\text { The government it self in the area and the } \\
\text { right to regulate and manage the household } \\
\text { alone }\end{array}$ \\
\hline 5 & Parliamentary democracy & Law No. 1/1957 & Principal staple of local government \\
\hline 6 & Guided democracy & Law No. 18/1965 & Principal staple of local government \\
\hline 7 & the new order & Law No. 5/1974 & Principal staple of local government \\
\hline 8 & Reformation & Law No. 22/1999 & Local government \\
\hline 9 & Reformation & Law No. 32/2004 & Local government \\
\hline
\end{tabular}

Source: Simanjuntak (2013)

With the implemented regional autonomy is expected to create efficiency and effectiveness in resource management which is owned by an area.Can improve the quality of public services and to improve the welfare of society. Can empower and create a space for people to take part in the process of regional development. With regional autonomy is expected to strengthen the economic base of the area which in turn can improve the welfare of the community.

\subsection{Fiscal Decentralization}

Implementation of the system of regional autonomy,followed by implementation of fiscal decentralization. Where the local government has the right to manage their own local financial. Based on the law of regional autonomy associated with the financial balance between the central government and the regions, revenue sources of region revenue are (Adisasmita, 2011):

\section{Region Revenue}

Sources of local revenues consist of: a) Results of local taxes; b) The results of levies; c) Results of the company-owned wealth management area and the results of other areas that are separated; d) Other income regional revenue legitimate.

\section{Balance fund}

The balancing fund consists of: a) Section blood from personal income tax receipts, Land and Building Tax, Customs Acquisition Rights dust and Building, and revenues from natural resources; b) General allocation fund, c) Special Allocation Fund.

\subsection{Flypaper Effect}

Oates (1999) states that when the response is greater regional spending on transfers than his own income, then it is called flypaper effect (Halim, 2002). Flypaper effect is an economic phenomenon when the government responded to the transfer given by central government in the form of general allocation funds greater use of the original income. Flypaper effect also affects the tendency of regional government expenditure for the next period so that the effect will result in the long term.

\subsection{Region Revenue}

According to Law No. 33 of 2004 article 1, paragraph 18 states that Region Revenue is a local earned income levied by local regulations in accordance with the legislation. Sources of regional revenue pursuant to article 6, paragraph 1 of Law No. 33 of 2004 consists of: local taxes, levies, local-owned company results and the results of the management of wealth belonging separated areas and others regional legitimate revenue. Furthermore, according to article 6 paragraph 2 of law mentioned above, other local revenue legitimate is covering the sale of the wealth of separated areas, current accounts, interest income, exchange gains in the rupiah against foreign currencies, commission pieces or other forms as result of the sale and or procurement of goods or services by regions. The aim of the income regional revenue is to provide authority for local governments to be able to self-fund the implementation of regional autonomy in accordance with the regional potential as a form of decentralization. 
The Phenomenon Flypaper Effect In Balanced Funds, Regional Revenue and Surplus Budget

\subsection{Balance Funds}

Implementation of fiscal decentralization in Indonesia is the provision of fiscal transfers to the region in the form of balance funds and special autonomy and adjustment fund. The fund balance is the reception area in the form of transfer income is the income of local government sourced from government transfer superiors recognized as an addition to net asset value. It is also stated in law No. 33 of 2004 and government regulation No. 55 Year 2005 balance fund consists of: Funds Revshare, General Allocation Fund and Special Allocation Fund. General allocation fund, which comes from the state government budget is allocated for the purpose of financial balance between the center and regions to finance the implementation of the decentralization of the general allocation fund is a block grant, which means the use of these funds delegated to the regions in accordance with the priorities and needs areas for improvement of services to the community in the implementation of regional autonomy which the legal basis for allocating these funds in accordance with law Number 33 of 2003 on the balance of funds between central and local magnitude general allocation fund is at least $26 \%$ of domestic revenues netto in the state budget. While the proportion of the general allocation fund for provincial and district/ municipal accordance with the needs and authority between provincial and district/city general allocation fund formula using the fiscal gap approach which is the difference between needs.Balance funds mentioned that the special allocation fund is a fund sourced from state government budget allocated to a particular region with the aim to help fund special activities of regional affairs in accordance with national priorities are implemented at the local level. Special allocation fund is earmarked for specific areas chosen for a special purpose.Funds revshare is a fund sourced from state government budget allocated to regions based on the percentage to finance the needs of the region in the implementation of decentralization (Law No.33 of 2004, On financial balance between central and local government). Funds Revshare transferred the central government to local government consists of two (2) types, namely tax funds revshare and funds revshare natural resources. Reception pattern of results was done by a certain percentage based on regions. Admissions Tax Revenue Sharing Fund sourced from:

a) Land and Building Tax,

b) Tax on Acquisition of Land and Building,

c) Income Tax Article 25 and Article 29 of the individual taxpayer of the Interior (Income WPOPDN) and Article 21 of the Income Tax (VAT 21).

d) While the reception Funds Revsharenatural resources from: Forestry, Mining General, Fisheries, Mining and Petroleum, Mining and Gas and Geothermal Mining

\subsection{Surplus Budget Funding}

Indonesian government regulation No. 71 Year 2010 states that the surplus budget funding is the difference between more / less between actual revenues and expenses during the reporting period. Surplus was the case in previous budget called the surplus budget funding. The presence or absence surplus budget funding and the size depends on the level of spending by the local governments as well as the performance of local revenue. If in a certain budget relatively low level of regional expenditure or occur efficiency of the budget, it is possible to be obtained surplus budget funding higher. But otherwise if regional expenditure is high, then surplus budget funding obtained will be smaller, even if regional expenditure larger than the area of income resulting fiscal deficit, and it happens timeless surplus budget funding.One source of funding for capital expenditure provision of public facilities is sourced from regional revenue surplus budget funding the previous fiscal year. Surplus budget funding is one source of funding used to cover the budget deficit as a result of efforts to increase the quality of care and welfare of society as explained in the PMK 45 / PMK.02 / 2006. If surplus budget funding area is quite large and is expected to finance all the regional capital expenditures for the provision of facilities and infrastructure to improve public services do not have to wait for help transfer funds from the central government.

\subsection{Regional Expenditure}

State revenue and expenditure budget and expenditure (commonly abbreviated APBD) the annual financial plan of local government were discussed and agreed upon by the regional government and the regional representative's council and determined by the regional regulation and became the basis of financial management in a period of one year from 1 January to 31 December. Budgets are an important instrument of government policy, which cannot be understood only as a more financial documents, but also reflects the commitment of the political and socio-economic policy priorities of the government.The structure of the budget consists of budgetary revenues, expenditures, and budget financing. Revenue is the right of local government areas recognized as an addition to net asset value in the period in question. Budget revenues are sourced from regional revenue, revenue-sharing and Other Income. Regional expenditure are all obligations that area recognized as a reduction in the net asset value of the relevant fiscal year period. 


\subsection{Regional Economic Growth Theory}

Regional economic growth is the increase in people's income as a whole is happening in the region, which is the entire added value that occurred (Tarin, 2014). The growth is the increase in output per capita in the long term (Boediono in Tarin, 2014). There are several factors that affect economic growth include the following: 1). Land and other natural resources, 2). The number and quality of population and workforce, 3 ). Capital goods and technology (Sukirno, 2004). Economic growth is one indicator of the success of economic development of a region. Where construction of the local government to precisely target the growth of the economy will increase. If the regional economic growth increases, the level of social welfare and productivity even higher, so that reduced unemployment and poverty will fall. Economic growth into one of the requirements to achieve economic development, but keep in mind not only the statistics that describe the growth rate, but rather the one who has created the economic growth, if only a few people or a large part of society (Todaro and Stephen C. Smith, 2006).

\section{Research Methods}

This research analysis method using quantitative analysis with panel data.The location of this research conducted at Regency / City in East Java with the study time period 2011-2015. The research data sourced from secondary data presented by the Directorate General of Fiscal Balance. This study uses panel data with the population in this study were 29 districts and 9 in East Java fiscal year 2011-2015.

Data were analyzed using panel data regression analysis with Eviews statistical test equipment. The regression equation is:

$$
\begin{array}{ll}
Y=\propto+\beta_{1} X_{1} & +\beta_{2} X_{2}+\beta_{3} X_{3}+\text { Kab } / \text { Kota }+e \\
\text { Where: } & =\text { direct expenditure and economic growth } \\
\mathrm{Y} & =\text { constant } \\
\propto & =\text { locally-generated revenue } \\
\mathrm{X}_{1} & =\text { difference financing articles } \\
\mathrm{X}_{2} & =\text { balance fund } \\
\mathrm{X}_{3} & =\text { a dummy variable } \\
\text { District / City } & \text { = error term } \\
\mathrm{E} & =\text { coefficient of regression } \\
\beta_{1} \beta_{2} \beta_{3} &
\end{array}
$$

\begin{tabular}{|c|c|c|c|c|}
\hline \multicolumn{5}{|c|}{ Dependent Variable: BELANJA } \\
\hline \multicolumn{5}{|c|}{ Method: Panel Least Squares } \\
\hline \multicolumn{5}{|c|}{ Date: $11 / 19 / 16$ Time: $16: 10$} \\
\hline \multicolumn{5}{|l|}{ Sample: 20112015} \\
\hline \multicolumn{5}{|l|}{ Periods included: 5} \\
\hline \multicolumn{5}{|c|}{ Cross-sections included: 38} \\
\hline \multicolumn{5}{|c|}{ Total panel (balanced) observations: 190} \\
\hline Variable & Coefficient & Std. Error & t-Statistic & Prob. \\
\hline PAD & -0.810229 & 0.273892 & -2.958202 & 0.0035 \\
\hline DAU & -0.840443 & 0.236534 & -3.553160 & 0.0005 \\
\hline SILPA & -1.387485 & 0.291732 & -4.756025 & 0.0000 \\
\hline $\mathrm{C}$ & 0.519450 & 0.094119 & 5.519098 & 0.0000 \\
\hline R-squared & 0.136445 & \multicolumn{2}{|c|}{ Mean dependent var } & 0.136706 \\
\hline Adjusted R-squared & 0.122516 & \multicolumn{2}{|c|}{ S.D. dependent var } & 0.085388 \\
\hline S.E. of regression & 0.079986 & \multicolumn{2}{|c|}{ Akaike info criterion } & -2.193094 \\
\hline Sum squared resid & 1.189993 & \multicolumn{2}{|c|}{ Schwarz criterion } & -2.124736 \\
\hline Log likelihood & 212.3439 & \multicolumn{2}{|c|}{ Hannan-Quinn criter. } & -2.165403 \\
\hline F-statistic & 9.796209 & \multicolumn{2}{|c|}{ Durbin-Watson stat } & 1.486242 \\
\hline Prob(F-statistic) & 0.000005 & & & \\
\hline
\end{tabular}

\section{Discussion and Analysis}

Regression test results where the dependent variable (regional expenditure), while independent variables (regional revenue, general allocation of funds, surplus budget funding) by using panel data from 2011 to 2015.Analyst research data using the program Eviews 7. The following is a regression test results:

Table 1.2 Regression Test Results

\section{The coefficient of determination (R2)}

The results of data analysis influence regional revenue, general allocation of funds and difference financing articles to regional expenditure in 38 district/city of East Java Province obtained the coefficient of determination, or R2 is 0.136445 , indicating that the variable regional revenue, general allocation of funds and 
difference financing articles contributed 13.64 percent in influencing regional expenditure all districts /city in East Java province. While the rest influenced by other factors or other variables that were not involved in this study. In general, the model used can be good to explain how the effect of (regional revenue, general allocation of funds, surplus budget funding, the regional expenditure districts/cities in East Java province.

\section{Simultaneous Testing (Test F)}

In the regression equation, the data analysis shows the calculated $\mathrm{F}$ value obtained at 9.796209 with probability equal to 0.0000 . When compared with Alpha 5\%, then the value obtained probability is smaller than the specified Alpha $(0.0000<0.05)$. Thus Ho rejected and concludes variable regional revenue, general allocation of funds and difference financing articles jointly significant effect on regional expenditure districts/cities in East Java province.In other words, the first hypothesis which states regional revenue, general allocation of funds and surplus budget funding positive influence on regional expenditure districts /city in East Java province, proved.

\section{Testing Partial (t-test)}

Testing this hypothesis using $t$ tests were conducted to show how far the influence of the independent variables individually in explaining the variation of the dependent variable. Based on $t$ test results, then the decision is as follows:

\section{Tests on variable regional revenue}

The first hypothesis states that regional revenue significant effect on regional expenditure. Based on calculations using the data eView program 7 showed that the significance value of 0.0035 . It means that decisions receive and reject $\mathrm{H}_{1} \mathrm{H}_{0}$, meaning regional revenue significant effect on regional expenditure because of the significance value less than 0.05 .

\section{Tests on variable general allocation of funds}

The second hypothesis states that general allocation of funds significant and positive impact on regional expenditure. Based on calculations using the data Eviews7 program showed that the significance value of 0.005. It means that decisions reject $\mathrm{H}_{0}$ and accept $\mathrm{H}_{2}$, meaning general allocation of funds significant effect on regional expenditure because the significance value less than 0.05 .

\section{Tests on variable surplus budget funding,}

The third hypothesis which states that surplus budget funding, significant effect on regional expenditure. Based on calculations using the data eView program 7 showed that the significance value of 0.000 . This means that decisions taken are received $\mathrm{H}_{3}$ and reject $\mathrm{H}_{0}$ means surplus budget funding, the positive significant effect on regional expenditure because of the significance value less than 0.05 .

Regression test results where the dependent variable (growth) while the independent variable (regional revenue, general allocation of funds, surplus budget funding) by using panel data from 2011 to 2015. Analysis research data using the program Eviews 7.The following is a regression test results:

Table 1.3 Regression Test Results

\begin{tabular}{|c|c|c|c|c|}
\hline \multicolumn{5}{|c|}{ Dependent Variable: GROWTH } \\
\hline \multicolumn{5}{|c|}{ Method: Panel Least Squares } \\
\hline \multicolumn{5}{|c|}{ Date: $11 / 19 / 16$ Time: $16: 13$} \\
\hline \multicolumn{5}{|l|}{ Sample: 20112015} \\
\hline \multicolumn{5}{|l|}{ Periods included: 5} \\
\hline \multicolumn{5}{|c|}{ Cross-sections included: 38} \\
\hline Variable & Coefficient & Std. Error & t-Statistic & Prob. \\
\hline PAD & 0.128673 & 0.062828 & 2.048022 & 0.0420 \\
\hline DAU & 0.075922 & 0.054258 & 1.399272 & 0.1634 \\
\hline SILPA & 0.058439 & 0.066920 & 0.873257 & 0.3836 \\
\hline $\mathrm{C}$ & 0.026074 & 0.021590 & 1.207684 & 0.2287 \\
\hline R-squared & 0.027523 & \multicolumn{2}{|c|}{ Mean dependent var } & 0.060897 \\
\hline Adjusted R-squared & 0.011838 & \multicolumn{2}{|c|}{ S.D. dependent var } & 0.018458 \\
\hline S.E. of regression & 0.018348 & \multicolumn{2}{|c|}{ Akaike info criterion } & -5.137759 \\
\hline Sum squared resid & 0.062617 & \multicolumn{2}{|c|}{ Schwarz criterion } & -5.069401 \\
\hline Log likelihood & 492.0871 & \multicolumn{2}{|c|}{ Hannan-Quinn criter. } & -5.110068 \\
\hline F-statistic & 1.754707 & \multicolumn{2}{|c|}{ Durbin-Watson stat } & 1.527012 \\
\hline Prob(F-statistic) & 0.157394 & & & \\
\hline
\end{tabular}

\section{The coefficient of determination ( $R 2)$}

The results of data analysis influence regional revenue, general allocation of funds, difference financing articles to growth in the 38 district/city of East Java Province obtained the coefficient of determination, or R2 is 0.027523 , indicating that the variable regional revenue, general allocation of funds, difference financing articles contributed 0.02 percent in growth affect all districts/city in East Java Province. 
While the rest influenced by other factors or other variables that were not involved in this study. In general, the model used can be good to explain how the effect of regional revenue, general allocation of funds, surplus budget funding, the growth districts/cities in East Java province.

\section{Simultaneous Testing (Test F)}

In the regression equation, the data analysis shows the calculated $\mathrm{F}$ value obtained at 1.754707 with probability equal to 0.026074 . When compared with Alpha 5\%, then the value obtained probability is smaller than the specified Alpha $(0.0000<0.05)$. Thus Ho rejected and concludes variable regional revenue, general allocation of funds, surplus budget funding jointly significant effect on growth districts/city in East Java province.In other words, the first hypothesis which states regional revenue, general allocation of funds, surplus budget funding positive effect on regional expenditure districts /city in East Java province, proved.

\section{Testing Partial (t-test)}

Testing this hypothesis using $t$ tests were conducted to show how far the influence of the independent variables individually in explaining the variation of the dependent variable. Based on $t$ test results, then the decision is as follows:

\section{Tests on variable regional revenue}

The first hypothesis states that regional revenue significant effect on growth. Based on calculations using the data eView program 7 showed that the significance value of 0.0420 . It means that decisions receive and reject $\mathrm{H}_{1} \mathrm{H}_{0}$, meaning regional revenue significant effect on spending because of the significance value less than 0.05 .

\section{Tests on variable general allocation of funds}

The second hypothesis states that general allocation of funds significant and positive impact on spending. Based on calculations using the data Eviews7 program showed that the significance value of 0.1634 . This means that the decision to accept $\mathrm{H}_{0}$ and reject $\mathrm{H}_{2}$, meaning that general allocation of funds has no effect on growth because of the significance value greater than 0.05 .

\section{Tests on variable surplus budget funding}

The second hypothesis which states that surplus budget funding significant effect on growth. Based on calculations using the data eView program 7 showed that the significance value of 0.3836 . This means that decisions taken are received $\mathrm{H}_{0}$ and reject $\mathrm{H}_{3}$ means surplus budget funding no effect on Growth because of the significance value greater than 0.05 .

Regression test results where the dependent variable (growth) while the independent variable (regional revenue, general allocation of funds, surplus budget funding, regional expenditure) by using panel data from 2011 to 2015.Analyst research data using the program Eviews 7. The following is a regression test results:

Table 1.4 Regression Test Results

\begin{tabular}{|c|c|c|c|c|}
\hline \multicolumn{5}{|c|}{ Dependent Variable: GROWTH } \\
\hline \multicolumn{5}{|c|}{ Method: Panel Least Squares } \\
\hline \multicolumn{5}{|c|}{ Date: $11 / 21 / 16$ Time: 09:02 } \\
\hline \multicolumn{5}{|l|}{ Sample: 20112015} \\
\hline \multicolumn{5}{|l|}{ Periods included: 5} \\
\hline \multicolumn{5}{|c|}{ Cross-sections included: 38} \\
\hline \multicolumn{5}{|c|}{ Total panel (balanced) observations: 190} \\
\hline Variable & Coefficient & Std. Error & t-Statistic & Prob. \\
\hline PAD & 0.093520 & 0.063299 & 1.477432 & 0.1413 \\
\hline $\mathrm{DAU}$ & 0.039458 & 0.055206 & 0.714742 & 0.4757 \\
\hline SILPA & -0.001760 & 0.069781 & -0.025219 & 0.9799 \\
\hline BELANJA & -0.043387 & 0.016561 & -2.619871 & 0.0095 \\
\hline $\mathrm{C}$ & 0.048611 & 0.022932 & 2.119785 & 0.0354 \\
\hline R-squared & 0.062312 & \multicolumn{2}{|c|}{ Mean dependent var } & 0.060897 \\
\hline Adjusted R-squared & 0.042038 & \multicolumn{2}{|c|}{ S.D. dependent var } & 0.018458 \\
\hline S.E. of regression & 0.018065 & \multicolumn{2}{|c|}{ Akaike info criterion } & -5.163662 \\
\hline Sum squared resid & 0.060377 & \multicolumn{2}{|c|}{ Schwarz criterion } & -5.078214 \\
\hline Log likelihood & 495.5479 & \multicolumn{2}{|c|}{ Hannan-Quinn criter. } & -5.129049 \\
\hline F-statistic & 3.073449 & \multicolumn{2}{|c|}{ Durbin-Watson stat } & 1.577357 \\
\hline Prob(F-statistic) & 0.017603 & & & \\
\hline
\end{tabular}

\section{The coefficient of determination ( $R 2)$}

The results of data analysis influence regional revenue, general allocation of funds, surplus budget funding and expenditure on growth in 38 district/city of East Java Province obtained the coefficient of determination, or R2 is 0.062312 , indicating that the variable regional revenue, general allocation of funds, surplus budget funding and expenditure contributed 0.06 percent in growth affects all districts/city in East Java 
province. While the rest influenced by other factors or other variables that were not involved in this study. In general, the model used can be good to explain how the effect of regional revenue, general allocation of funds, surplus budget funding and regional expenditure, the Growth districts/city in East Java province.

\section{Simultaneous Testing (Test F)}

In the regression equation, the data analysis shows the calculated $\mathrm{F}$ value obtained at 9.796209 with probability equal to 0.0354 . When compared with Alpha 5\%, then the value obtained probability is smaller than the specified Alpha $(0.0000<0.05)$. Thus Ho rejected and concludes variable regional revenue, general allocation of funds and surplus budget funding jointly significant effect on regional expenditure districts/cities in East Java province. In other words, the first hypothesis which states regional revenue, general allocation of funds and surplus budget funding positive effect on regional expenditure districts/cities in Eat Java Province, is proven.

\section{Testing Partial (t test)}

Testing this hypothesis using $t$ tests were conducted to show how far the influence of the independent variables individually in explaining the variation of the dependent variable. Based on $t$ test results, then the decision is as follows:

\section{Tests on variable regional revenue}

The first hypothesis states that regional revenue significant effect on growth. Based on calculations using the data eViews program 7 showed that the significance value of 0.1413 . It means that decisions reject and accept $\mathrm{H}_{1} \mathrm{H}_{0}$, meaning that the regional revenue does not affect the growth because of the significance value greater than 0.05 .

\section{Tests on variable general allocation of funds}

The second hypothesis states that general allocation of funds significant and positive impact on the growth. Based on calculations using the data program Eviews7 showed that the significance value of 0.4757 . This means that the decision received $\mathrm{H}_{0}$ and reject $\mathrm{H}_{2}$, meaning general allocation of funds no significant effect on growth because of the significance value less than 0.05 .

\section{Tests on variable surplus budget funding}

The second hypothesis which states that surplus budget funding significant effect on growth.Based on calculations using the data program eViews 7 showed that the significance value of 0.9799 . This means that decisions taken are starting $\mathrm{H}_{3}$ and accept $\mathrm{H}_{0}$ means no significant effect difference financing articles positively to growth for more than significance value of 0.05 .

\section{Tests on regional expenditure variable}

The second hypothesis which states that the regional expenditure significant effect on growth. Based on calculations using the data eView 7. The program showed that the significance value of 0095. This means that decisions taken are received $\mathrm{H}_{4}$ and reject $\mathrm{H}_{0}$ means spending a significant positive effect regional growth because of the significance value less than 0.05 .

\subsection{Analysis of Regional Revenue to Regional Expenditure}

Regional revenue positively affects regional expenditure in the district /city in the province of East Java. This means that the higher revenue generated, the area also increases the regional expenditure issued by the local government. Decentralization model that provides a space for autonomous local governments to increase revenue creation give the impact of the increase in regional revenue. Therefore, with increasing regional revenue will increase spending/regional expenditure.Regional revenue positive effect on regional spending as regional revenue is a major source of government revenue derived from the resources within the region itself. regional revenue is the area of revenues generated from sources within its own territory levied by local regulations in accordance with the legislation in force. Regional revenue can be sourced from taxes, charges, and revenue receipts are valid under the law.

Regional revenue is one indicator for assessing the independence of a region and a benchmark for the success of the local government in the implementation of government functions, development, and delivery of public services to the community. The local government district/city in East Java province should explore potential originating from its territory in order to increase revenue so it does not rely on the central government transfer.The results are consistent with research conducted by Ilma Syahida Arofi (2015). The results of this study indicate that the regional revenue and the general allocation fund positive effect on regional spending. Then simultaneously it can be concluded that a significant difference between regional revenue and the general allocation fund to regional expenditure. As well as research Deny Oktavia (2014) regional revenue and the general allocation fund in general positive effect on the regional expenditure. 


\subsection{Analysis of General Allocation Funds to Regional Expenditure}

General Allocation Fund positively affects regional expenditure at the district/city in the province of East Java. This means that the higher the general allocation funds obtained from the central government also increase the regional expenditure incurred by local governments. General allocation fund is one source of local revenue that comes from central government funds sourced from the state budget to be allocated for the purpose of financial equalization between regions to fund operational needs of the area. With the increase of general allocation funds to the region led to an increase in regional expenditure district/city in East Java Province is expected to improve public services provided by regional governments to the public. So with the increase of general allocation funds also have a positive impact on the people in the district /city in East Java province.The results are consistent with research conducted by Ilma Syahida Arofi (2015). The results of this study indicate that the regional revenue and the general allocation fund positive effect on regional spending. Then simultaneously it can be concluded that a significant difference between regional revenue and the general allocation fund to regional expenditure. As well as research Deny Oktavia (2014) regional revenue and the general allocation fund is generally positive influence on regional expenditure.

\subsection{Analysis of Surplus Budget Funding to Regional Expenditure}

Surplus budget funding positively affects regional expenditure at the district/city in the province of East Java. This means that the higher the general allocation funds obtained from the central government also increase the regional expenditure incurred by local governments.Large or small financing budget surplus is probably the best indicator of the efficiency of management funds. The greater the financing budget surplus district /city, the most efficient management of these funds. Conversely, when financing budget surplus city /county small then the inefficient management of these funds. The financing budget surplus area is quite large and is expected to finance all the regional capital expenditures for the provision of facilities and infrastructure to improve public services do not have to wait for help transfer funds from the central government.

\subsection{Analysis on the Growth of Regional First Revenue}

Based on the statistical test $t$ can be concluded that the original income positive effect on the growth of the district /city in East Java province.Regional revenue growth on a positive influence on district /city in East Java province. Regional revenue should be the main fund which is managed by the local government in an era of fiscal sentrasisali and regional autonomy so that the Regional government does not just rely on funds from the central government. Regional revenue affects regional economic growth in the district /city in East Java show that the government's role is very important especially in the allocation of local budget. Spending areas need to be taken seriously in order to be allocated in earnest in productive sectors and projects with management and good management and transparent so that it will increase the productivity of the economy in order to achieve an increase in growth.One of the main objectives of fiscal decentralization is the realization of capabilities in terms of local finance (financial independence), which local governments are expected to explore the financial resources of the region through regional revenue. Areas that have high levels of positive regional revenue growth have the possibility to increase income per capita better, so as to give effect positively to my growth in the economy of a region. If the original income increases then the fund will be managed area for construction also increased. In meaning the greater the revenue area is obtained, then the level of expenditure will move to rise, so there is a tendency to spend funds local budgets. With increasing regional revenue indicates the better the government to optimize the potential that exists in the area. By multiplying the potential in the area will have a positive impact on the population in the surrounding area. So with increases, regional revenue can increases growth in the area.

\section{Analysis of Regional Expenditure on Growth}

Regional expenditure positive influence on growth at district/city in East Java province. With increased spending on growth areas indicate that many local governments use the budget to the public interest which can stimulate growth at the district /city in East Java province. Regional expenditure can be grouped into two recurrent expenditure and development expenditure Routine expenditure have little impact on growth because government spending is spending that is not productive and tend to be consumptive. Meanwhile, development expenditure having an impact on the strengthening of the economy because government spending is used for investment in development that can have a multiplier effect on the growth of the area.

Your spending government areas may be capital goods, infrastructure development that may have an impact on regional growth. The rate of economic growth of a region can increases if expenditures of local governments meet the objectives of the development plan both short term and long term. If government spending were mostly reserved for activities such as infrastructure investment and economic social such as the construction of bridges, roads, water, electricity, transportation, telecommunications to facilitate and integration for economic activity can increase the productivity of economic activities that can bind economic growth. 
Economic development can not be separated from economic growth in which economic development to encourage economic growth, or vice versa. Increased government spending may provide increased influence a country's ability to produce goods and services from one period to the next. Growth is one of the prerequisites of development, the relatively smaller can near disadvantaged areas towards convergence with more developed areas. Government spending is one measure that affects the economy and is a form of stimulus by the government in the early stages of development. This is related to government spending has a role as a fiscal instrument can be via the function allocation, distribution, and stabilization. The allocation of expenditure should take precedence in the crucial functions than just routine. Regional expenditure can be no effect on growth if regional expenditure used by the government expenditures. Efficiency and effectiveness regional expenditure can be seen as a positive influence on growth.

\subsection{Analysis Flypaper Effect on Regional Expenditure District Municipality in East Java Province}

Flypaper effect is a condition where the stimulus (response) in regional spending caused by the change in the number of general allocation fund transfers from the central government is greater than that caused by changes in local revenue. This is certainly contrary to the principle of decentralization and autonomy principles, where local governments are required to be more independent without relying on the central government. Determining the occurrence of flypaper effect can be done by comparing two coefficients of independent variables are general allocation fund with regional revenue, in which the general allocation fund coefficient value is greater than the coefficient of regional revenue and both significant, insignificant or regional revenue. The regression coefficient between general allocation fund coefficient of $t-3.553160-0.840443$ with probability 0.0005 and then at 0.05 Alpha general allocation fund statistically significant effect on public expenditures, while the value of the coefficient of regional revenue as $t-2.958202-0.810229$ with probability 0.0035 and then Alpha 0.05 regional revenue statistically significant effect on their spending.

The results of the comparison coefficient general allocation fund and regional revenue indicates there has been a flypaper effect on regional expenditure district/city in East Java Province, because the general allocation fund coefficient greater than regional revenue, and both significantly general allocation fund $=$ $0.840443>$ regional revenue $=-0.810229$ ). Thus the second hypothesis which states that there has been flypaper effect in regional expenditure 38 districts/city in East Java province, proved . This study proves the government district /city in East Java province yet financially independent because it has not been able to rely on their own areas of financial capability in running the government. Hence the need for an increase in revenue receipts areas with efforts to explore the potential in each area based on excellence comparative and excellence absolute.

The results are consistent with research conducted by Danang Ariwijaya (2013). These results indicate that the effect of general allocation funds towards regional expenditure is stronger than the effect of regional revenue. It indicates the occurrence of flypaper effect. The results also showed that regional revenue $\mathrm{t}-1$ has a stronger predictive power than regional revenuet-1 in influencing the prediction regional expenditure. The results of this study also proves that the phenomenon occurs flypaper effect on ducation expenditure. The results also demonstrate the effect of regional revenue to health spending is greater than the influence of general allocation fund. The results also demonstrate the effect of regional revenue to expenditure public works is greater than the influence of general allocation fund. The results also prove there is a difference between the occurrence of flypaper effect district/city high regional revenue by district/city that regional revenue is low.Furthermore, the results support their research is research Deny Oktavia. Shows the results of testing to show that the time series data in 2003-2013 occurred flypaper effect indicated by general allocation fund more significant influence on regional expenditure of the regional revenue to the influence of regional expenditure. Districts/cities in East Java generally experience flypaper effect proven or accepted, regional expenditure response was greater due to the equalization funds, particularly from general allocation fund component.

\section{Conclusion and Recommedation}

Based on the research The Phenomenon Flypaper Effect In Balanced Funds, Regional Revenue And Surplus Budget Funding Of Economic Growth And Regional Expenditure In Districts/City Province East Java in 2011-2015 it can be concluded as follows:

1. Region revenue positive effect on regional expenditure. This means that the higher revenue generated region, the area also increase the expenditure incurred by the government district /city in East Java province.

2. General allocation fund positive effect on regional expenditure. This means that the higher the general allocation funds received from the government district /city in East Java province, the area also increase the expenditure incurred by the government of the district/city in East Java province.

3. Financing budget surplus positive influence on Expenditure on Government district /city in East Java province. More high general allocation funds obtained from the central government spending is increasing 
as well regions issued by local governments. Large or small budget financing difference is probably the best indicator of the efficiency of management funds.

4. Regional revenue growth on a positive influence on the district /city in East Java Province.

5. Regional Expenditure affects positively the growth at the district/city in East Java Province.

6. There was flypaper effect phenomenon occurred in the district/city in the province of East Java. It means the government of district /city in East Java Province is still very dependent on central government expenditure in the area this is evidenced by the use of general allocation funds is more dominant than the original income.

Based on the research The Phenomenon Flypaper Effect In Balanced Funds, Regional Revenue And Surplus Budget Funding Of Economic Growth And Regional Expenditure In Districts/City Province East Java in 20112015, the researchers gave the following advice:

1. For local government is expected to increase the independence and reduce the dependence of local governments on the funds given by the central government. district/city in the province of East Java could increase regional revenue by maximizing the regional revenue notably from local taxes, levies and other things that can be a legitimate source of revenue.

2. For the local government in order to explore the potential existing in the region based on the comparatif advantage and absolute advantage.

3. Manage the budget efficiently and optimize budget management in the public sector, so that with the increase in government spending can also expect a direct or indirect impact on the community so as to promote growth.

4. Make capital formation or investment area through the regional website to attract investors to the region to promote development that might impact on growth.

5. For further research is recommended to further develop this research by adding other variables that are not addressed in this study instance variables gross regional domestic product and government policies.

\section{References}

[1] Adisasmita, Raharjo. 2011. Pengelolaan Pendapatan dan Anggaran Daerah. Yogyakarta: Graha Ilmu.

[2] Ariwijaya, Danang. 2013. Flypaper Effect Pada Dana Alokasi Umum (DAU) Dan Pendapatan Asli Daerah (PAD) Terhadap Belanja Daerah Pada Kabupaten/Kota Di Provinsi Jawa Timur.

[3] Arofi, Ilma Syahida .2015.Pengaruh Flypaper Effect Pada Pendapatan Asli Daerah ( PAD ) Dan Dana Alokasi Umum (DAU) Terhadap Belanja Daerah ( BD ) Periode 2012 - 2014 ( Studi Kasus : Kabupaten/Kota Provinsi Jawa Timur)

[4] Bailey, S.J. dan S. Connolly, (1998), “The Flypaper Effect: Identifying Areas for Further Research", Public Choice, 95(3/4), Juni: 335-58.

[5] Becker, E., (1996), "The Illusion of Fiscal Illusion: Unsticking the Flypaper Effect", Public Choice, 86(1/2), Februari: 85-102.

[6] Bradford, D. dan W. Oates. 1971a. The Analysis of Revenue Sharing in a New Approach to Collective Fiscal Decisions. Quarterly Joernal of Economics 83

[7] dan_ 1971b. Towards a Predictive Theory of Intergovernmental Grant. American Economic Review 61 (2): 440448

[8] Chalid, Pheni. 2005. Otonomi Daerah Masalah, Pemberdayaan dan Konflik. Jakarta: Kemitraan.

[9] Darwanto \& Yulia Yustikasari. 2007. "Pengaruh Pertumbuhan Ekonomi, Pendapatan Asli Daerah, Dana Alokasi Umum Terhadap Pengalokasian Belanja Modal". Simposium Nasional Akuntansi X Makasar 26-28 Juli 2007.

[10] DJPK, Direktorat Jenderal Perimbangan Keuangan, Kementerian Keuangan Republik Indonesia.

[11] Donderdag 02 Mei 2013 pengertian pertumbuhan ekonomi yang di kutip dari Boediono, 1992. Teori Pertumbuhan Ekonomi, Yogyakarta : BPF

[12] Fillimon, R., T. Romer, dan H. Rosenthal, (1982), “Asymmetric Information and Agenda Control”, Journal of Public Economics, 17(2), Februari: 51-70.

[13] Gramlich, E.M., (1977), "Intergovernmental Grants: A Review of the Empirical Literature”, dalam W.E. Oates, (Ed.), The Political Economy of Fiscal Federalism, Lexington Books, Lexington MA: 219-40.

[14] Gorodnichenko, Y., (2001), Effects of Intergovernmental Aid on Fiscal Behavior of Local Governments: The Case of Ukraine, Master Thesis, University of Kiev, http://www.eerc.kiev.ua/research/matheses/2001/pdf/ gorodnichenko.pdf

[15] Grossman, P.J., (1990), “The Impact of Federal and State Grants on Local Government Spending: A Test of the Fiscal Illusion Hypothesis", Public Finance Quarterly, 18(3), Juli: 313-27.

[16] Gujarati, Damodar, N. dan Porter, Dawn C.. 2010. Dasar-dasar Ekonometri. Buku 1. Jakarta.Penerbit Salemba Empat.

[17] Gujarati, Damodar, N. dan Porter, Dawn C.. 2012. Dasar-dasar Ekonometri. Buku 2. Jakarta.Penerbit Salemba Empat.

[18] Halim, Abdul \& Syukriy Abdullah. 2006. "Hubungan dan masalah keagenan di pemerintahan daerah: sebuah peluang penelitian anggaran dan akuntansi”. Jurnal Akuntansi Pemerintah 2(1).

[19] Halim, Abdul. 2007. Akuntansi Sektor Publik Akuntansi Keuangan Daerah. Jakarta: Salemba Empat.

[20] ------ 2009. Akuntansi Sektor Publik Akuntansi Keuangan Daerah. Jakarta: Salemba Empat.

[21] Harahap, Alfan. 2010. "Pengaruh Dana Bagi Hasil Pajak dan Dana Sumber Daya Alam terhadap Belanja Modal Pada Kabupaten/Kota di Sumatera Utara". Skripsi. Universitas Sumatera Utara.

[22] Harianto, David \& Priyo Hari Adi. 2007. "Hubungan Antara Dana Alokasi Umum, Belanja Modal, Pendapatan Asli Daerah dan Pendapatan Per Kapita”. Simposium Nasional Akuntansi X Makasar 26-28 Juli 2007.

[23] Jhingan, M.L. 2012. Ekonomi Pembangunan dan Perencanaan. Jakarta: PT. Raja Grafindo Persada.

[24] Kaho, Jose Riwu. 2003. Prospek Otonomi Daerah di Negara Republik Indonesia. Jakarta: PT Raja Grafindo Persada.

[25] Kuncoro, Haryo. 2004. Pengaruh Transfer Antar Pemerintah Pada Kinerja Fiskal Pemerintah Daerah Kota dan Kabupaten Di Indonesia. Jurnal EkonomiPembangunan Kajian Ekonomi Negara Berkembang Vol. 9 No. 1, Juni 2004 Hal: 47 - 63.

[26] Logan, R.R., (1986), "Fiscal Illusion and the Grantor Government", Journal of Political Economy, 94(6), November/Desember: 1304-18. 
[27] Maharani, Mayzestika. 2010. "Pengaruh Pertumbuhan Ekonomi, Pendapatan Asli Daerah, dan Dana Alokasi Umum, Terhadap Belanja Modal Pada Pemerintah Daerah se Jawa Tengah”. Skripsi. Universitas Negeri Semarang.

[28] Mangkoesoebroto, Guritno. 2014. Ekonomi Publik Edisi Ketiga. Yogyakarta: BPFE.

[29] Mardiasmo. 2002. Akuntansi Sektor Publik. Yogyakarta: Andi.

[30] McGuire, M.C., (1973), "Notes on Grant-in-Aid and Economic Interactions among Governments", Canadian Journal of Economics, 6(2), Mei: 207-21.

[31] Megasari . Ida Ayu Gede Sutha .2015. Pengaruh Pendapatan Asli Daerah, Selisih Lebih Perhitungan Anggaran Dan Flypaper Effect Pada Perilaku Oportunistik Penyusun Anggaran.

[32] Ndadari, Laras Wulan, dan Priyo Hari Adi. 2008. Perilaku Asimetris Pemerintah Daerahterhadap Transfer Pemerintah Pusat. Makalah disampaikan dalam The 2nd National Conference UKWMS. Surabaya. 6 September 2008.

[33] Oates, W.E., (1979), "Lump-Sum Intergovernmental Grants Have Prices Effects", dalam P.M. Mieszkowski dan W.H. Oakland, (Ed.), Fiscal Federalism and Grants-in-Aid, The Urban Institute, Washington, DC: 23-30.

[34] Oates, W.E., (1994), "Federalism and Government Finance”, dalam J. Quigley dan E. Smolensky, (Ed.), Modern Public Finance, Harvard University Press, Cambridge, MA: 126-51.

[35] Oktavia, Deni. 2014. Flypaper Effect: Fenomena Serial Waktu Dan Lintas Kabupaten Kota Di Jawa Timur 2003-2013. Jurnal Akuntansi Universitas Jember. Vol 12 No. 2 Des 2014

[36] Peraturan Pemerintah Nomor 55 Tahun 2005 tentang Dana Perimbangan.

[37] Peraturan Pemerintah Nomor 58 Tahun 2005 tentang Pengelolaan Keuangan Daerah .

[38] Schwallie, D.P., (1989), The Impact of Intergovernmental Grants on the Aggregate Public Sector, Quarum Books Greenwood Press, New York.

[39] Siagian, Pamela Augustina. 2009. Flypaper Effect pada Pendapatan Asli daerah (PAD) dan Dana Alokasi Umum (DAU) terhadap Belanja Daerah Pada Pemerintahan Kab/Kota di Propinsi Sumatera Utara.

[40] Simanjutak, Bungaran Antonius. 2013. Dampak Otonomi Daerah di Indonesia Merangkai Sejarah Politik dan Pemerintah Indonesia. Jakarta: Yayasan Obor Indonesia.

[41] Sukirno, sadono. 2004. Makro ekonomi. Cetakan ke 5, edisi 3. Jakarta: PT Raja Grafindo

[42] Tarigan, Robinson. 2005. Ekonomi Regional (Teori dan Aplikasi). Jakarta: Bumi Aksara

[43] Tiebout, C.M., (1956), "A Pure Theory of Local Expenditure”, Journal of Political Economy, 64(5), Oktober: 416-24.

[44] Todaro, Michael P dan Smith, Stephen C. 2006. Pembangunan Ekonomi. Edisi Sembilan. Jakarta: Erlangga.

[45] Turnbull, G.K., (1998), "The Overspending and Flypaper Effect of Fiscal Illusion: Theory and Empirical Evidence", Journal of Urban Economics, 44(1), Juli: 1- 26.

[46] Turnbull, G.K., (1992), "Fiscal Illusion, Uncertainty, and the Flypaper Effect”, Journal of Public Economics, 48(2), Juli: 207-23.

[47] Undang-Undang Nomor 22 Tahun 1999, tentang Pemerintahan Daerah. Sekretariat Negara Republik Indonesia.

[48] Undang-Undang Nomor 25 Tahun 1999, tentang Perimbangan Keuangan Antara Pemerintah Pusat Dan Daerah. Sekretariat Negara Republik Indonesia.

[49] Undang-Undang Nomor 32 Tahun 2004, tentang Pemerintahan Daerah. Sekretariat Negara Republik Indonesia

[50] Undang-Undang Nomor 33 Tahun 2004, tentang Perimbangan Keuangan Antara Pemerintah Pusat dan Pemerintah Daerah. Sekretariat Negara Republik Indonesia.

[51] Wahyuni dan Priyo Hari Adi. 2009. "Analisis Pertumbuhan Dan Kontribusi Dana Bagi Hasil Terhadap Pendapatan Daerah (Studi Pada Kabupaten/Kota Se Jawa-Bali)”. National Conference UKWMS Surabaya.

[52] World Bank, 1997, on line Source Book On Decentralization And Rural Development, Decentralization Thematic Team.

[53] Yani, Ahmad. 2002. Hubungan Keuangan antara Pemerintah Pusat dan Daerah di Indonesia. Jakarta : PT. Raja Grafindo Persada.

[54] Yovita, Farah Marta. 2011. "Pengaruh Pertumbuhan Ekonomi, Pendapatan Asli Daerah dan Dana Alokasi Umum Terhadap Pengalokasian Anggaran Belanja Modal (Studi Empiris pada Pemerintah Provinsi Se Indonesia Periode 2008 - 2010)”. Diponegoro Jurnal Of Accounting. Semarang: UNDIP 